\title{
On the Growth of European Apparel Firms
}

By: Nancy J. Nelson Hodges and Albert N. Link

Hodges, N.J., \& Link, A.N. "On the Growth of European Apparel Firms," Journal of the Knowledge Economy, 2017, 8: 489-498. https://doi.org/10.1007/s13132-016-0443-z

This version of the article has been accepted for publication, after peer review (when applicable) and is subject to Springer Nature's AM terms of use, but is not the Version of Record and does not reflect post-acceptance improvements, or any corrections. The Version of Record is available online at: http://dx.doi.org/10.1007/s13132-016-0443-z.

\begin{abstract}
:
According to the European Skills Council, the apparel industry is experiencing a renaissance in countries throughout the European Union, and this renaissance is marked by innovation and technical development among small firms. In this paper, the AEGIS database is used to estimate a growth model for the apparel industry. The annual rate of growth of European apparel firms is modeled and measured in terms of growth in number of employees since the firm was founded. The model is presented through descriptive statistical analyses on the relevant variables that were used to estimate this dimension of firm performance - founder characteristics including gender and education, as well as whether the firm is family owned. The model has implications for identifying factors important to apparel firm growth that could help in policy development designed to foster increased industry growth.
\end{abstract}

Keywords: apparel industry | entrepreneurship | employment growth | gender | family governance

\section{Article:}

\section{Introduction}

During the past 25 years, the global apparel industry has changed dramatically. What was once a domestic industry in both the USA and Europe has now largely moved off-shore to become a geographically complex and oftentimes fragmented value chain. As a low-tech, low-skilled industry, apparel firms began seeking out locations with low cost labor from its very beginnings, but for some, it was the end of the quota restrictions and trade agreements such as NAFTA that signaled the end of the domestic manufacturer (Gereffi 2000; Taplin 2006). Advanced economies, like those of the USA and European Union (EU), no longer have the degree of manufacturing that they once had (Hodges and Lentz 2010; Taplin and Winterton 2004). Jobs in apparel manufacturing witnessed a parallel decline throughout the end of the 20th and into the early twenty-first century (Hodges and Karpova 2006).

Recently, it has been suggested that the industry is returning to its domestic roots, albeit slowly. This resurgence is happening in the form of entrepreneurial small businesses seeking to manufacture apparel using local supply chain partners in the process. Known in the USA by the 
term reshoring, there is a growing trend among apparel firms looking to rebuild the domestic job economy and focusing on innovation as well as technical change as the means to achieve this goal. The same trend may also be happening in the European Union, where, according to the European Skills Council (2014), there is a renaissance happening in the apparel industry, some of which can be attributed to a focus on innovation by small sized entrepreneurial firms.

Designed to investigate the extent to which innovation is fueling growth across EU industries, as will be discussed in Section III of the paper, the AEGIS project was conducted with the help of small firms across EU countries and in both high- and low-technology sectors. Specifically, the AEGIS database was initiated to identify how firms use knowledge and innovation for growth. The premise behind including both high- and low-tech industries was that the latter often tend to be overlooked in research on innovation as a driver of growth, including such industries as apparel and textiles (Hirsch-Kreinsen 2006; Schwinge 2015). Although it may be characterized as low-tech, the apparel industry is important, not just to the economies of countries throughout Europe, but also in terms of exports coming from the European Union (European Commission 2015):

The textile and clothing sector is an important part of the European manufacturing industry, playing a crucial role in the economy and social well-being in many regions of Europe. According to data from 2013, there were 185,000 companies in the industry employing 1.7 million people and generating a turnover of 166 billion euros. The sector accounts for a $3 \%$ share of value added and a $6 \%$ share of employment in total manufacturing in Europe.

Regardless of whether an industry is high- or low-tech, it is important to understand how firms within it behave in order to better shape policies that can help to foster growth. This is particularly true in terms of increased employment growth. As one factor of firm performance, employment numbers had been on the decline in the EU apparel industry until 2010 when modest increases started to occur (European Commission 2014). The purpose of this paper, therefore, is to investigate the factors that may lead to increases in employment growth among small EU apparel firms. Our findings have relevance for understanding how similar kinds of growth may be achieved by small apparel firms within other advanced economies, such as the USA.

The remainder of the paper is outlined as follows. In Section II, we present our model of firm growth. In Section III, we discuss the AEGIS database, the source from which our sample of European apparel firms comes. Using the AEGIS data, we are able to estimate the annual rate of growth of European apparel firms measured in terms of their growth in employees since being founded. ${ }^{1}$ In Section IV, we present descriptive statistics on the relevant variables that we use to estimate our growth model, and we present and discuss our statistical findings. Section V concludes the paper with summary remarks.

\section{A Model of Firm Growth}

\footnotetext{
${ }^{1}$ Our focus in this paper on the European apparel industry not only reflects the conspicuous void of systematic empirical research on that industry in general, but also it complements our own research agenda.
} 
As we mentioned in Section I, we are measuring the growth of apparel firms in terms of their growth in employees over time. We let the number of firm employees at time $t$, be represented as $y(t)$, and we assume that employment growth over time can be represented as an exponential function:

$$
y(t)=a e^{g t} e^{\varepsilon}
$$

where the initial number of employees in the firm when founded is denoted by $a, g$ is the annual growth rate of employees, and $\varepsilon$ is a random error term.

We hypothesize that the growth rate of employees, $g$, is a function of explanatory variables $x_{1}$ through $x_{\mathrm{k}}$ as follows:

$$
g=b_{0}+b_{1} x_{1}+\ldots b_{k} x_{k}
$$

From Eq. (1), $g$ can be calculated as the percentage change in employees, $g(t)$, over time, $t$ :

$$
g=(\partial y(t) / \partial t) / y(t)
$$

Also, we can transform Eq. (1) by taking the logarithm of both sides:

$$
\ln y(t)=\ln a+g t+\varepsilon
$$

Substituting $g$ from Eq. (2) into Eq. (4), and redefining $y(t)$ using the variable notation employeesyear, yields a model that can be estimated empirically ${ }^{2}$ :

$$
\text { lnemployees }_{\text {year }}=\ln a+b_{0} t+b_{1} x_{1} t+\ldots b_{k} x_{k} t+\varepsilon
$$

Using the estimated values of the coefficients from Eq. (5) (i.e., the estimated value of the b's) and the mean values of the $x$ 's, we can calculate mathematically the average annual growth rate of employees in the apparel firms in our sample.

\section{The AEGIS Database}

The AEGIS (Advancing knowledge-intensive entrepreneurship and innovation for growth and social well-being in Europe) database was constructed as part of the European Commission's 7th Framework Programme (FP7). The intent of constructing the AEGIS database was to assemble information on entrepreneurial firms, which are assumed to be engines of economic growth and societal well-being. More specifically, an explicit objective of the data collection effort was to further an understanding of the "defining characteristics, boundaries, scope and incentives" of entrepreneurial firms (PLANET 2011, p. 5).

\footnotetext{
${ }^{2}$ Link and Scott $(2003,2006)$ previously estimated a growth model similar to that in equation (5) using a sample of employees in U.S. science and technology parks.
} 
The firms included in the AEGIS database are not a random sample of European enterprises. In order to have a large enough sample to study firms in all countries, the architects of the database realized, correctly in our opinion, that firms in smaller countries (e.g., Croatia and the Czech Republic) needed to be sampled at a higher rate than firms in larger countries (e.g., France and Germany). To account for the non-random sampling, sample weights have generally been used in relation to the statistical analyses. ${ }^{3,4}$

Table 1. AEGIS Survey definition of components of the European apparel industry

\begin{tabular}{|ll|}
\hline 18 & Manufacture of wearing apparel, dressing, and dyeing of fur \\
\hline 18.1 & Manufacture of leather clothes \\
& 18.10 Manufacture of leather clothes \\
& Manufacture of other wearing apparel and accessories \\
& 18.21 Manufacture of workwear \\
& 18.22 Manufacture of other outerwear \\
& 18.23 Manufacture of underwear \\
& 18.24 Manufacture of other wearing apparel and accessories n.e.c. \\
Dressing and dyeing of fur; manufacture of articles of fur & 18.30 Dressing and dyeing of fur; manufacture of articles of fur \\
\hline
\end{tabular}

Source: “Classification of Economic Activities, NACE Rev.1.1” www.instat.gov.al/media/166724/nace_rev.1.1.pdf

Table 2. Distribution of AEGIS firms in the European apparel industries, by country

\begin{tabular}{|lc|}
\hline Country & Number of apparel firms \\
\hline Croatia & 6 \\
Czech Republic & 3 \\
Denmark & 2 \\
France & 9 \\
Germany & 3 \\
Greece & 14 \\
Italy & 27 \\
Portugal & 11 \\
Sweden & 4 \\
United Kingdom & $\underline{5}$ \\
Total & 84 \\
\hline
\end{tabular}

Source: AEGIS database

The AEGIS database contains information on 4004 firms established between 2001 and 2007 across 10 European countries. ${ }^{5}$ The AEGIS survey was conducted in 2011 , so at a minimum a firm in the AEGIS sample would have been active for 4 years. ${ }^{6}$ The countries represented in the

\footnotetext{
${ }^{3}$ Caloghirou et al. (2011) provide detailed information on the sampling process.

${ }^{4}$ The sampling weights are, by country: Croatia (11.985), Czech Republic (15.230), Denmark (23.909), France (100.249), Germany (66.470), Greece (12.628), Italy (89.371), Portugal (16.492), Sweden (62.533), and United Kingdom (21.764). However, as Link and Swann (2016) showed, weighted results are not more predictive than nonweighted results.

${ }^{5}$ Recent papers using the AEGIS database include Cunningham and Link (2016) and Link and Swann (2016).

${ }^{6}$ Some of the surveys were conducted in late-2010, but we do not have information on which firms were interviewed in 2010 and which were interviewed in 2011. Because most of the interviews were conducted in 2011, we use that year as the survey year.
} 
database are (alphabetically): Croatia, Czech Republic, Denmark, France, Germany, Greece, Italy, Portugal, Sweden, and the United Kingdom.

The definition of the apparel industry, as defined by the AEGIS database, is shown in Table 1, and the distribution of the 84 apparel firms in the database, by country, is shown in Table 2.

\section{Estimation of the Growth Model}

The dependent variable in an estimable version of Eq. (5), Inemployees 2011, is the logarithm of employees, employees, in each apparel firm at the time of the AEGIS survey in 2011. Regarding the independent variables, $t$ is calculated as (2011-year the firm was founded). All of the apparel firms in the AEGIS database were founded between 2001 and 2007.

The other independent variables of interest are as follows. The variable family is a dichotomous variable equal to 1 if the firm was founded using 100\% funding from the family's own resources, and 0 otherwise. The variable female is also dichotomous; it equals 1 if the primary founder of the firm is a female, and 0 if it is a male. ${ }^{7}$ Finally, the variable education equals the number of years of education of the primary founder. Each of these independent variables is multiplied by $t$ based on the mathematical construction of Eq. (5).

We have no hypothesis about the directional relationship between employment growth and family. The performance of family-owned firms, especially small family-owned firms in the apparel industry, has not previously been addressed in the academic literature.

There is a general literature related to the performance of small firms by gender of ownership, female, but again that literature is not specific to the apparel industry. The extant literature suggests that in general, there is no substantial evidence of differences between small firm performance of women-owned and men-owned businesses in either the USA or in international countries (Link and Strong 2016).

We hypothesize that there will be a negative relationship between employment growth and the educational level of the primary founder, education. Founder education is likely correlated with founder age, although the AEGIS database does not contain a reasonable measure of founder age. ${ }^{8}$ Younger founders might be more enthusiastic about their family-funded firm and thus it might grow faster.

Descriptive statistics on these key variables are in Table 3. Note that in the AEGIS sample of apparel firms, $45.2 \%$ are family owned as we have defined that variable; $35.7 \%$ were founded by a female, and the average level of education of the primary founder is 13.3 years, that is slightly more than a high school education.

\footnotetext{
${ }^{7}$ Some of the apparel firms reported having more than one founder. We assume that the primary founder is the first founder listed in the AEGIS survey database (Caloghirou et al. 2011).

${ }^{8}$ The AEGIS survey question asked about the primary founder's age in terms of decades (such as age 19 through 29 or age 30 through 39 , and so forth).
} 
Table 3. Descriptive statistics on the variables used in Eq. (5) $(n=84)$

\begin{tabular}{|lccc|}
\hline Variable & Mean & Standard deviation & Range \\
\hline employees $_{2011}$ & 11.74 & 12.47 & $1-71$ \\
Inemployees $_{2011}$ & 1.94 & 1.11 & $0-4.26$ \\
$t^{\prime}$ & 7.12 & 2.34 & $4-10$ \\
family & 0.452 & 0.501 & $0 / 1$ \\
female $_{\text {education }}$ & 0.357 & 0.482 & $0 / 1$ \\
\hline
\end{tabular}

Note: The number of employees in a firm in 2011 equals the number of full-time employees plus 2 times the number of part-time employees (i.e., 2 part-time employees equal 1 full-time employee)

A correlation matrix of the variables is in Table 4. The correlation coefficients in the table offer suggestive information about the directional influence of the three key variables on employment growth. The correlation coefficient between lnemployees2011 and family is negative and significant. The correlation coefficient between lnemployees 2011 and female is also negative and significant. Finally, the correlation coefficient between lnemployment 2011 and education is negative, as hypothesized, but only marginally significant. However, the size of these correlation coefficients does not suggest a problem with collinearity among the independent variables in the estimation below.

Table 4. Correlation matrix of the variables

\begin{tabular}{|lcccc|}
\hline & Inemployees 2011 & family & female & education \\
\hline lnemployees 2011 & 1 & & & \\
family & $-0.271^{* *}$ & 1 & & \\
female & $-0.234^{* *}$ & -0.029 & 1 & \\
education & $-0.193^{*}$ & 0.054 & -0.101 & 1 \\
\hline
\end{tabular}

*Significant at 0.10 -level

**Significant at 0.05 -level

$* * *$ Significant at $0.01-$ level

The regression results from the estimation of Eq. (5) are in Table 5. Note that we have included non-linear values of $t$ to account for non-linear growth over time. With regard to the results in column (1), employment growth has indeed been non-linear, but that is to be expected because the European economy as a whole, and the European apparel industry in particular, has been in decline since the early 2000s and especially during the 2008-2009 recession. Our model shows employment growth declining and then mildly increasing. The latter increase might reflect a modest recovery of the industry in 2010 and 2011. The estimated coefficients on $t, t^{2}$, and $t^{3}$ are not statistically significant but that is to be expected because those three variables are highly correlated; the estimated coefficients are, however, economically significant.

The regression results in column (1) also show that founder characteristics do matter and are identifiable covariates with employment growth. The regression coefficient on family $x t$ is negative and marginally statistically significant. The sign on female $x t$ and on education $x t$ is also negative, and both coefficients are statistically significant. The direction of these relationships is expected from the correlation matrix in Table 4. 
Table 5. Regression results from Eq. (5) (standard errors in parentheses, $p$ values in brackets, $n=84$ )

\begin{tabular}{|c|c|c|}
\hline Variable & (1) & (2) \\
\hline \multirow[t]{3}{*}{$t$} & -2.159 & -1.490 \\
\hline & $(2.950)$ & (2.915) \\
\hline & [0.467] & [0.611] \\
\hline \multirow[t]{3}{*}{$t^{2}$} & 0.438 & 0.311 \\
\hline & $(0.439)$ & $(0.435)$ \\
\hline & {$[0.322]$} & {$[0.177]$} \\
\hline \multirow[t]{3}{*}{$t^{3}$} & -0.024 & -0.017 \\
\hline & $(0.021)$ & $(0.021)$ \\
\hline & {$[0.262]$} & {$[0.410]$} \\
\hline \multirow[t]{3}{*}{ family $x t$} & $-0.055^{* *}$ & $-0.048^{*}$ \\
\hline & $(0.031)$ & $(0.030)$ \\
\hline & [0.077] & [0.114] \\
\hline \multirow[t]{3}{*}{ female $x t$} & $-0.074 * * *$ & $-0.068 * * *$ \\
\hline & $(0.032)$ & $(0.032)$ \\
\hline & {$[0.023]$} & {$[0.038]$} \\
\hline \multirow[t]{3}{*}{ education $x t$} & $-0.011 * * *$ & $-0.00033^{* *}$ \\
\hline & $(0.005)$ & $(0.00018)$ \\
\hline & {$[0.023]$} & {$[0.075]$} \\
\hline \multirow[t]{3}{*}{ Portugal $x t$} & - & 0.056 \\
\hline & & $(0.047)$ \\
\hline & & {$[0.237]$} \\
\hline \multirow[t]{3}{*}{ Greece $x t$} & - & 0.055 \\
\hline & & $(0.041)$ \\
\hline & & [0.189] \\
\hline \multirow[t]{3}{*}{ France $x t$} & - & $-0.105^{* *}$ \\
\hline & & $(0.061)$ \\
\hline & & $(0.089)$ \\
\hline \multirow[t]{3}{*}{ Intercept } & 5.311 & 3.969 \\
\hline & (6.287) & (6.189) \\
\hline & {$[0.401]$} & $(0.523)$ \\
\hline$R^{2}$ & 0.240 & 0.306 \\
\hline$F$-level & $3.95 * * * *$ & $3.52 * * * *$ \\
\hline
\end{tabular}

*Significant at 0.15 -level

** Significant at 0.10 -level

$* * *$ Significant at 0.05 -level

$* * * *$ Significant at 0.01 -level

On the basis of Eq. (2) above, the relevant values of the $b$ 's are the regression coefficients in Table 5, and the relevant values of the $x$ 's are the mean values of the corresponding variables. Thus, based on the regression results in column (1) of the table, the average annual rate of employment growth rate of apparel firms over the 2001 through 2011 time period across all apparel firms in all countries in the AEGIS database is $-45.4 \%$, calculated as follows:

$g=-2.159+0.438(t)-0.024\left(t^{2}\right)-0.055($ family $)-0.074($ female $)-0.011$ (education) 
where the mean values of the independent variables are used in Eq. (6). ${ }^{9}$ That is, employment growth declined between 2001 and 2011 by an annual rate of $45.4 \%$, and that decline was greater among family-owned firms, female-founded firms, and firms with founders with greater education as evidenced by the negative sign on those coefficients. ${ }^{10}$ Of this decline, familyowned firms contribute only 2.5 percentage points (i.e., -0.55 (family)) and female-founded firms contribute only 2.6 percentage (i.e., -0.074 (female)) points. ${ }^{11}$

While we have identified statistically significant variables associated with the decline in employment growth among apparel firms over the period 2001 through 2011, the economic significance of family or gender ownership is minimal in comparison to the overall state of the European economy - the apparel segment of the economy in particular - during this period. Based on data reported by the European Commission (2014), the apparel industry throughout the European Union has been in decline since the early 2000s, only showing a modest recovery beginning in 2010. A number of other factors that we could not measure, such as innovations to each firm's business model (Carayannis et al. 2014) and cross-firm differences in their ability to respond to national growth policies (Carayannis and Rakhmatullin 2014), are certainly important to explaining employment growth.

We attempted to calculate country-specific growth rates by including a country-specific binary variable time $t$ in an estimable version of Eq. (5). A number of the country-specific variables were highly correlated with either family or female, and thus they were deleted. ${ }^{12}$ The regression results in column (2) of Table 5 are limited from a country perspective, but they do provide a suggestion that there are cross-country differences in the rate of employment growth of apparel firms. For example, employment growth over the 2001-2011 period was mildly greater among Portuguese and Greek apparel firms and mildly less among French apparel firms.

\section{Concluding Remarks}

It is important to emphasize that the empirical findings from this exploratory study should be interpreted cautiously. To the best of our knowledge, our systematic study of AEGIS apparel firms is the first to identify statistically founder characteristics associated with firm performance - employment growth specifically. However, our sample of firms is small and thus one should not generalize from our findings to the European industry as a whole. That said, our findings do suggest that future research related to the performance of apparel firms might emphasize founder characteristics as a variable of interest.

The fact that we have identified variables, other than time, that have a measurable economic impact on employment growth, also open the door for additional research. We mentioned above

\footnotetext{
${ }^{9}$ Recall that -2.159 is the regression coefficient on $t$ in equation (5), but only the coefficient enters into calculation of $g$ in equation (2).

${ }^{10}$ As points of possible comparison, available Eurostat data show that between 2005 and 2011 employment in the apparel industry in Italy declined at an average annual rate of $20.1 \%$; it declined at an average annual rate of $29.5 \%$ in Portugal; and it declined at an average annual rate of $43.4 \%$ in France.

${ }^{11}$ Another way to think about this conclusion is as follows. The average annual rate of decline in employment growth among apparel firms that are not family-owned, that are male-founded, and that have a founder with 13.27 years of education was $40.3 \%$.

12 These results are available from the authors on request.
} 
several such variables - business model innovation and national growth policies - but there is an additional variable that scholars might consider. That variable is the social network of the founders (Leyden and Link 2015; Scuotto et al. forthcoming). Our analysis did emphasize founder education, and education might or might not be correlated with the extent of one's social network, but more explicit measures are in our view clearly warranted especially since theory highlights social networks as one driver of growth (Leyden and Link 2015).

\section{Acknowledgements}

The authors wish to thank the AEGIS consortium for providing data of the AEGIS survey which supported the empirical investigation of knowledge-intensive entrepreneurship in Europe in different sectoral, country, and socioeconomic contexts. This survey was conducted in the context of the AEGIS research project (Advancing Knowledge-Intensive Entrepreneurship and Innovation for Economic Growth and Social Well-being in Europe) co-funded by the European Commission under Theme 8 "Socio-Economic Sciences and Humanities" of the 7th Framework Programme for Research and Technological Development.

\section{References}

Caloghirou Y, Protogerou A, Tsakanikas A (2011) “Advancing knowledge-intensive entrepreneurship and innovation: Final report summarizing survey methods and results for economic growth and social well-being in Europe," mimeograph

Carayannis, E. G., Grigoroudis, E., Sindakis, S., \& Walter, C. (2014). Business model innovation as antecedent of sustainable enterprise excellence and resilience. J Knowl Econ, 5, 440463.

Carayannis, E. G., \& Rakhmatullin, R. (2014). The quadruple/quintuple innovation helixes and smart specialisation strategies for sustainable and inclusive growth in Europe and beyond. J Knowl Econ, 5, 212-239.

Cunningham, J. A., \& Link, A. N. (2016). Exploring the effectiveness of research and innovation policies among European Union countries. Int Entrep Manag J, 12, 415-425.

European Commission (2014). Helping firms grow: European competitiveness report, 2014. Belgium: Brussels.

European Commission (2015). Textiles and clothing in the EU. Belgium: Brussels.

European Skills Council (2014). European sector skills council textile clothing leather footwear report 2014, Brussels European Skills Council.

Gereffi, G. (2000). The transformation of the north American apparel industry: is NAFTA a curse or a blessing? Integration and Trade, 4, 47-95.

Hirsch-Kreinsen, H., Jacobson, D., \& Robertson, P. (2006). 'Low-tech’ industries: innovativeness and development perspectives - a summary of a European research project. Prometheus, 24, 3-21. 
Hodges, N. J., \& Karpova, E. (2006). Employment in the U.S. textile and apparel industries: a comparative analysis of regional vs. national trends. J Fash Mark Manag, 10, 209-226.

Hodges, N. J., \& Lentz, H. (2010). U.S. textile sector job loss: implications for individuals, communities and industry. J Fash Mark Manag, 14, 21-38.

Leyden, D. P., \& Link, A. N. (2015). Toward a theory of the entrepreneurial process. Small Bus Econ, 44, 475-484.

Link, A. N., \& Scott, J. T. (2003). U.S. science parks: the diffusion of an innovation and its effects on the academic missions of universities. Int $J$ Ind Organ, 21, 1323-1356.

Link, A. N., \& Scott, J. T. (2006). U.S. university research parks. J Prod Anal, 25, 43-55.

Link, A. N., \& Strong, D. R. (2016). Gender and entrepreneurship: an annotated bibliography. Foundations and Trends in Entrepreneurship, 12, 287-441.

Link, A. N., \& Swann, C. A. (2016). R\&D as an investment in knowledge based capital. Journal of Industrial and Business Economics, 43, 11-24.

PLANET (2011) “Advancing knowledge-intensive entrepreneurship and innovation for economic growth and social well-being in Europe," D5.4 Final Report

Schwinge, I. (2015). The paradox of knowledge-intensive entrepreneurship in low-tech industries: evidence from case studies of the German textile industry. Wiesbaden, Germany: Springer.

Scuotto, V., Del Giudice, M., \& Carayannis, E. G. (forthcoming). The effect of social networking sites and absorptive capacity on SMES' innovation performance. J Technol Transfer. doi:10.1007/s10961-016-9517-0.

Taplin, I., \& Winterton, J. (2004). The European clothing industry: meeting the competitive challenge. J Fash Mark Manag, 8, 256-261.

Taplin, I. (2006). Restructuring and reconfiguration: the EU textile and clothing industry adapts to change. Eur Bus Rev, 18, 172-186. 